\title{
INDIA IN 2008
}

\author{
Domestic Turmoil and \\ External Hopes
}

\section{Sumit Ganguly}

\section{Abstract}

The past year saw significant domestic turmoil in India. The country confronted a series of terrorist attacks including the one in Bombay, witnessed ethno-religious violence, dealt with a resurgent Maoist (Naxalite) guerilla movement, and faced agitations from agricultural communities over the acquisition of land for industrialization. On the external front, India managed to consummate a critical civilian nuclear agreement with the U.S., after much domestic debate and contention.

Keywords: Naxalite agitation, terrorism, U.S.-India civilian nuclear agreement, Nandigram, economic downturn

\section{Introduction}

Communal violence, terrorist attacks and bombings, and internal conflicts wracked significant parts of India throughout 2008. In addition, a dramatic spike in global oil prices, coupled with rising food prices, delivered considerable exogenous shocks to the country's economy. Late in the year, the acute financial crisis in the U.S. began having an adverse, but limited, impact on India's economy. Despite these myriad problems stemming from both domestic and external sources, the country managed to clock a growth rate of $7.9 \%$ in the quarter ending in June. ${ }^{1}$

Sumit Ganguly is Professor of Political Science and holds the Rabindranath Tagore Chair in Indian Cultures and Civilizations at Indiana University in Bloomington. E-mail: <sganguly@indiana.edu>.

1. Times of India, <http://timesofindia.indiatimes.com/At_79_GDP_quarterly_growth_ drops_to_3-year_low/rssarticleshow/3423549.cms>, accessed on October 16, 2008.

Asian Survey, Vol. 49, Issue 1, pp. 39-52, ISSN 0004-4687, electronic ISSN 1533-838X. (C) 2009 by The Regents of the University of California. All rights reserved. Please direct all requests for permission to photocopy or reproduce article content through the University of California Press's Rights and Permissions website, at http://www.ucpressjournals.com/reprintInfo.asp. DOI: AS.2009.49.1.39. 
Amid all of these disturbing developments and significant domestic opposition, the Congress-led United Progressive Alliance (UPA) successfully negotiated a landmark civilian nuclear accord with the U.S. The national government now confronts the task of realizing some of the potential gains from this agreement for addressing India's acute energy needs. The events of the past year underscore two very conflicting trends in the Indian polity. On the one hand, the country continues its moderately rapid rate of economic growth despite infrastructural bottlenecks in energy and transportation, not to mention unexpected external shocks. On the other, politically motivated violence, growing religious radicalism, failures of governance, and administrative inefficiencies continued to hobble the country's developmental progress.

\section{Economic Conditions and Prospects}

In strictly aggregate terms, India's economic performance remained quite robust. Yet, a more nuanced analysis reveals that this growth is regionally quite uneven; significant parts of the country have seen swift economic growth while others remain serious laggards. For example, economic conditions in many eastern states - notably Orissa, Jharkhand, Bihar, and West Bengal-remain depressed; growth appears to be stalling in some southern states, particularly Kerala; and the west appears to be ceding ground to a resurgent north, despite bright spots like Gujarat. Contrary to popular belief, statistical evidence shows that some small northern states like New Delhi, Himachal Pradesh, and the substantially agricultural state of Punjab now enjoy the most robust economic indicators. In contrast, western India, which had witnessed substantial growth in the initial flush of economic liberalization, has shown signs of slowing down. ${ }^{2}$ Apart from these regional disparities, which are likely to create important tensions for fiscal federalism in India, the growth of absolute inequality has also become the subject of important debate in both academic and political circles. Votaries of economic liberalization are quick to underscore that this rapid economic growth has contributed to the overall reduction of poverty, whereas those who have qualms about India's fitful embrace of market liberalization focus on the increased inequality emerging during this period.

A number of converging external and domestic factors will probably contribute to a general slowdown of India's economic growth in the coming year, with potentially significant consequences for the upcoming national elections scheduled for 2009. For example, inflation started to flare during

2. On this subject, see India Today, <http://indiatoday.digitaltoday.in/content_mail.php? option=com_content\&name=print $\%$ id $=15109>$, accessed on October 16, 2008. 
2008 because of the global spike in petroleum prices and the increased cost of food items, which rose about $15 \%{ }^{3}$ In October, the overall rate of inflation hovered around $12 \%{ }^{4}$ These trends suggest a slowing down of India's recently dramatic growth rate. In all likelihood, matters will worsen further as the full impact of the global financial crisis begins to affect India's markets more acutely. One of the repercussions of the expanding global financial crisis is likely to be a slowing down of India's fitful steps toward economic liberalization. Faced with inflationary pressures and an impending election, the Congress-led government is unlikely to undertake steps that would result in short-term dislocation through privatization and fiscal austerity. ${ }^{5}$

Although electoral cycles will inevitably affect the pace of economic liberalization, other political factors will also have an impact on India's industrial growth, possibly accentuating the country's regional economic disparities. The Tata conglomerate's effort to build the cheapest car in the world, the Nano, is illustrative of the lingering difficulties of promoting industrialization in certain parts of India. In an attempt to provide middle-class Indians with a small, fuel efficient, and inexpensive car, the scion of the Tata conglomerate, Ratan Tata, charged his automotive engineering and design staff to manufacture such a vehicle. The state of West Bengal, which has witnessed industrial stagnation over the past several decades, sought to attract both foreign and domestic investment. To this end, it acquired 1,000 acres of land from a farming community about 40 kilometers from the capital city of Calcutta (Kolkata). The Tatas located their principal manufacturing unit on this land, and a number of ancillary suppliers were also moving in when Mamata Banerjee, a local politician and leader of the Trinamool (Grassroots) Congress, attempted to garner electoral gains by convincing a group of farmers that the state government had not adequately compensated them for their land. Demonstrations soon ensued and continued into the fall, often resulting in violence. State government officials and members of the ruling Communist Party of India (Marxist) attempted to mediate, and even the governor of West Bengal, Gopal Krishna Gandhi, offered his good offices.

3. Jonathan Robins, "India's Economy: Slowing but Still Delivering," South Asia Monitor, no. 122, September 2, 2008 (Washington, D.C.: Center for Strategic and International Studies, South Asia Program, 2008).

4. Joe Leahy and Varun Sood, "Storm Darkens India's Festive Mood," Financial Times, October18/19, 2008.

5. Nandini Lakshman, "What Economic Reform? As Indian Inflation Rises, Prime Minister Singh Has Little Time Left to Push Privatizing State Companies and Other Financial Reforms," Business Week Online, August 14, 2008; available at <http://www.businessweek. com/globalbiz/content/aug2008/gb20080813_183226.htm>. 
In September, the Trinamool Congress called off its agitation but still refused to accept the concessions the state government was willing to make to the aggrieved farmers. Faced with this political uncertainty and with the distinct prospect of further demonstrations and violence at the plant site, Ratan Tata chose in October to dismantle the plant even though he had invested as much as $\$ 350$ million into its construction. ${ }^{6}$ Shortly thereafter, he shifted the manufacturing hub for the Nano to the western state of Gujarat, which offered him highly attractive terms. The possible merits of the farmers' claims aside, this episode underscored the continuing difficulties that lie ahead in attempting to transform India's rural landscape.

\section{Ethnic Tensions, Religious Violence, and Civil Conflict}

Widespread civil violence and a range of ethno-religious conflicts continued in India through 2008. The bulk of ethno-religious violence was confined to particular areas of the country, especially Kashmir, Karnataka, and Orissa, whereas the civil violence was much more dispersed. In particular, civil violence in the form of the contemporary Maoist Naxalite movement afflicted as many as 14 out of 28 states in the Indian Union. ${ }^{7}$ Considering the widespread nature of the Naxalite insurgency, Prime Minister Manmohan Singh referred to it as being the single most important internal security issue facing the nation. ${ }^{8}$ Unfortunately, the response of both the central government as well as various state governments to the Naxalite insurgency has been piecemeal and inept. Ironically, India's federal structure has hampered the central government's ability to fashion a coherent, national strategy to tackle the problem because law and order is a state responsibility. In the absence of a near complete breakdown of public order or without the express request of the afflicted state, the central government cannot send its security forces to confront the Naxalites.

Why is India abruptly witnessing a recrudescence of the Naxalite movement? ? $^{9}$ Most popular accounts focus on the apparent adverse impact of India's gradual adoption of market-oriented economic reforms and the

6. "Tata Pulls Out of Singur," Financial Express, October 6, 2008, available at $<$ http:// www.financialexpress.com/news/Tata-pulls-out-of-Singur/369707/>, accessed on October 19, 2008.

7. Data obtained from South Asia Terrorism Portal, <http://www.satp.org/satporgtp/ countries/India /index.html>, accessed on October 17, 2008.

8. The Mint (Bombay), <http://www.livemint.com/2007/12/20230429/Naxal-menace-posesbiggest-sec.html?d=1>, accessed on October 16, 2008.

9. The original Naxalite movement can be traced to the late-1960s in the state of West Bengal. For a discussion of its origins and demise, see Ranjit Kumar Gupta, The Crimson Agenda: Maoist Protest and Terror (New Delhi: Wordsmiths, 2004). 
putative exacerbation of steep economic inequality. ${ }^{10}$ Yet, this argument is not entirely sound because economic inequality has been a constant in India since its independence. One could argue, however, that the increased awareness of these economic inequalities and the political mobilization of these grievances help explain the recurrence of Naxalite violence better than the mere existence of economic inequalities alone. Some of the coercive strategies adopted by state authorities have also exacerbated matters. In the state of Chattisgarh, for example, state authorities have created what amounts to village-based auxiliary police forces, known as the Salwa Judum (literally, "Peace Mission"), to confront the Naxalites. These entities are composed of villagers with rudimentary, if any, police training, armed with crude weaponry. Their lack of professional training and consequent feckless behavior have contributed to gross human rights violations and have done little to contain the Naxalite threat.

Simultaneously, the country also witnessed the emergence of a new, indigenous radical Muslim group, the self-styled Indian Mujahideen (Fighters for God). According to its own claims, the group was responsible for setting off bombs in Jaipur, Bangalore, Ahmedabad, and New Delhi. ${ }^{11}$ The growth of indigenous Muslim radicalism in India can be traced to two important sources. At one level, it has its origins in the discrimination that the vast majority of Muslims have faced in public life in the country. At another, its sudden emergence can be attributed to the increased political awareness of young, lower-middle class Muslims about their status within India. Political developments in other parts of the Islamic world - especially in the aftermath of the terrorist attacks of September 11, 2001-undoubtedly have also influenced their political consciousness. Ample empirical evidence about their comparative socioeconomic conditions can be adduced; however, the argument about the external impact on their political outlook can only be established on the basis of inference and attribution.

For example, some of the statistical evidence available from the Justice Rajinder Sachar Commission Report of 2006 - a government-sponsored analysis of the condition of the Muslim community - provides a clear sense of Muslims' marginal status in Indian public life. The analysis found that although Muslims constitute 13\% of the country's population, they occupied a mere $3 \%$ of all positions in the elite Indian Administrative Service, $1.8 \%$ in the coveted Indian Foreign Service, and only $4 \%$ in the powerful Indian Police Service. In turn, the comparatively lower educational

10. This is the central argument proffered in Sudeep Chakravarti, Red Sun: Travels in Naxalite Country (New Delhi: Penguin, 2007).

11. See British Broadcasting Corporation, <http://news.bbc.co.uk/2/hi/south_asia/7622341. stm>, accessed on October 16, 2008. 
attainment of the community as a whole also helps explain their lack of competitiveness in entering these critical public services. Given these persistent inequalities, it is hardly surprising that some young Muslim youth feel sufficiently disaffected from the Indian state to respond to the siren call of radical Islam.

The growing radicalization of small pockets of the Indian Muslim community, unless curbed through both ameliorative public policy initiatives and in some limited instances through coercive means, could pose a significant problem for long-term social stability in India. ${ }^{12}$ Unfortunately, the national and state governments' handling of an inadvertent crisis in India's only Muslim-majority state, Kashmir, in July and August 2008, raised profound questions about the ability of Indian politicians to respond with such sagacity and competence. The new crisis in Jammu and Kashmir arose from an apparently innocuous decision on the part of the state government to transfer 100 acres of publicly owned land in June to the Shri Amarnath Shrine Board, a quasi-public body responsible for the welfare of Hindu pilgrims who make the long annual trek to the Amarnath Shrine in the Himalayan range in Kashmir. The land was to be used to erect shelters for the pilgrims.

Syed Ali Shah Geelani, a local Islamist leader with secessionist and proPakistani proclivities, promptly mobilized his followers in the wake of the announced land transfer. To that end, he made the mendacious assertion that the land transfer was a devious plot to alter a constitutional provision prohibiting non-Kashmiris from acquiring land in the state. His rhetoric provoked the misgivings of a significant number of Kashmiri Muslims, who also have other compelling reasons for doubting the motivations of the Indian state. Even though India has managed to curb the insurgency that flared up in the Muslim-majority Kashmir Valley beginning in 1989, its harsh tactics have contributed to a deep reservoir of discontent and anger among much of Kashmir's population. A large number of Kashmiri youth took to the streets to express their resentment in the wake of Geelani's dubious claim against the state government.

When confronted with this sudden display of public discontent, one of the partners of the ruling coalition in the state, the People's Democratic Party (PDP), withdrew its support for the land transfer and the government. This led to the fall of the PDP-Congress coalition government in Jammu and Kashmir; the central government, following constitutional provisions, subsequently took over the affairs of the state including replacing the governor, retired General Srinivas Kumar Sinha, with a respected

12. Matthew Rosenberg, "Experts: Indian Police Struggle to Halt Bombings," Associated Press, July 29, 2008. 
retired bureaucrat, Narendra Nath Vohra. Vohra, in an attempt to assuage the anger of the Muslims of the Kashmir Valley, rescinded the land transfer order.

Almost immediately, Vohra's decision provoked a counterreaction in Jammu, the southern part of the state, where Hindus are a majority. Egged on by the hyper-nationalist Bharatiya Janata Party (Indian People's Party, BJP), Hindu chauvinists took to the streets in protest of the governor's decision. The central government, which had largely been a passive bystander to these developments, finally chose to act and address the grievances of all the communities involved in the controversy. After much discussion, negotiations with all parties succeeded in containing the agitation both in the Kashmir Valley and in Jammu, but not before considerable damage had been done to life, property, and commerce. ${ }^{13}$ It was eventually agreed to that the land would be temporarily made available to the pilgrims, but that the structures erected for their protection would be dismantled after the pilgrimage ended.

Tragically, ethno-religious violence in India was not confined to only Hindu-Muslim tensions in 2008. The country's minuscule Christian community, a mere $2 \%$ of the total population, faced a series of attacks, most notably in the states of Orissa and Karnataka. ${ }^{14}$ The proselytizing zeal of evangelical Christian missionaries was the ostensible reason for these attacks. ${ }^{15}$ Yet, a more careful analysis suggests that several other factors were at work as well. One was the exigency of electoral politics. With the national election approaching next year, the BJP's affiliate - the Bajrang Dal (the Party of Hanuman) - has sought to solidify its political base in some key states. ${ }^{16}$ To that end, it raised the bogey of rampant Christian missionary activity designed to elicit mass conversions of Hindus. Though the veracity of this claim was utterly dubious, it nevertheless succeeded in triggering widespread anxiety among segments of the Hindu population in various states. Another factor that helps explain the rise of violent antiChristian sentiment in both Orissa and Karnataka is the fact that a number of Christian converts in these states are from the lowest rungs of the caste ladder, the untouchables (dalits), who have insisted that they still retain the privileges that were initially afforded to them in employment and

13. Sumit Ganguly, "Pacifying Kashmir," Asian Wall Street Journal, August 21, 2008.

14. Kim Barker, "Radical Hindus Step up Attacks on Christians," Chicago Tribune, September 27, 2008.

15. Sumit Ganguly, Forbes, "The Murder of Christians," October 16, 2008, available at <http://www.forbes.com/opinions/2008/10/15/murder-christians-india-oped-cx_sg_1016 ganguly.html>, accessed on October 18, 2008.

16. Hanuman is the monkey-god of Hinduism who, according to Hindu tradition, led an army against the demon king Ravana. 
education through India's "positive discrimination" (affirmative action) schemes. These demands have also attracted the opprobrium of radical Hindu elements, often of higher caste background. ${ }^{17}$

Other forms of ethnic assertiveness were seen in India's Northeast region. In June, activists belonging to the Gurkha Janamukti Morcha (GJM, Gurkha People's Liberation Agitation) in the northern part of West Bengal renewed their agitation for the creation of a separate state within the Indian Union in the Himalayan foothills. An earlier spate of agitation had resulted in the creation of "hills councils" for the Gurkhas and the granting of increased political autonomy. The demonstrations in the summer, while causing considerable dislocation to tourist traffic and commerce, did not turn violent. The government of West Bengal expressed its willingness to negotiate, but ruled out the creation of a separate state. For their part, leaders of the GJM have agreed to meet the chief minister of West Bengal, Buddhadeb Bhattacharya, to discuss their demands. The Gurkhas, who are frequently mistaken to be Nepalese, contend that statehood would place their ethnic identity on secure footing. ${ }^{18}$

In the neighboring state of Assam, another ethnic movement, that of the Bodo tribal community, is showing signs of recrudescence. In early October, Bodos attacked several Muslim communities, claiming that the latter were illegal immigrants from neighboring Bangladesh. Some 53 people died and 150,000 were displaced in this fracas before the police could restore order. The problem of illegal immigration from Bangladesh is undeniable; some estimates put the number as high as two million. However, quite apart from the vigilante violence of the Bodos, it is not entirely clear that the hapless victims were illegal immigrants; they may have been Indian Muslims who settled in Assam well over 30 years ago. ${ }^{19}$

Finally, yet another "sons of the soil" movement appears to be brewing in the city of Bombay (Mumbai) in the state of Maharashtra. This movement is spearheaded by the Maharashtra Navnirman Sena (Maharashtra Reconstruction Army) - a variant of the Shiv Sena (the Army of Shiva) which is a local, anti-immigrant, nativist party. ${ }^{20}$ Initially, the Shiv Sena had spearheaded an agitation against internal migrants from various southern

17. Mian Ridge, "Anti-Christian Attacks Flare in India," Christian Science Monitor, September 24, 2008.

18. "Redrawing the Map of Gorkhaland," Indian Express, June 12, 2008.

19. "Bodo Count: Assam's Largest Tribe Goes to War with Its Muslims," Economist, October 11, 2008.

20. James Fontenella-Khan and Amy Kazmin, "Hindu Leader Held after Migrant Attacks," Financial Times, October 22, 2008. Shiva is a major Hindu god who is often depicted as the destroyer or transformer in Hindu religious tradition. 
states. Subsequently, in the face of considerable deindustrialization in and around Bombay, they had successfully scapegoated the Muslim community. The targets of their latest populist rage appear to be lower-class migrants from the impoverished states of Bihar and Uttar Pradesh. ${ }^{21}$ It is unlikely that this agitation will end soon, and the national economic downturn may actually make matters worse.

\section{Foreign Relations}

Despite a spate of domestic problems, Manmohan Singh's government succeeded in pushing through a significant foreign policy initiative - the U.S.-India civilian nuclear agreement. This agreement for all practical purposes placed India in the ranks of de facto nuclear weapons states. It will enable India to freely participate in most forms of civilian nuclear commerce and also bring its long global isolation in the realm of nuclear technology to a close. ${ }^{22}$ Under the terms, India will place 14 of its 22 nuclear reactors under International Atomic Energy Agency (IAEA) safeguards, while the other eight will remain off limits. With the agreement now in place, India has already started negotiations with France and Russia for various types of nuclear technology, including reactors. It is likely that major American firms will soon enter the Indian commercial nuclear market as well.

Yet, ensuring the successful culmination of this nuclear deal was not without domestic political controversy. Just before the Congress-led UPA government was about to approach the 45-nation Nuclear Suppliers Group for approval of the treaty in July, the Communist parties, in a political pique because of their intransigence toward the U.S., withdrew their parliamentary support for the UPA government, forcing Prime Minister Singh to desperately cobble together sufficient backing to survive a noconfidence motion. In the end, the Singh government garnered enough votes but not before it was subjected to a spate of scurrilous accusations of bribery to obtain the necessary votes. ${ }^{23}$

The culmination of the nuclear deal in October marked a milestone in the transformation of Indo-U.S. relations because it removed a significant diplomatic irritant. However, it would be incorrect to assume that the relationship is now free of all differences. For instance, India remains skeptical,

21. Vir Sanghvi, "The Bhaiyya Effect," Hindustan Times, February 23, 2008.

22. Sumit Ganguly, "Time to Seize the Day," World Policy Blog, September 12, 2008, available at <http://worldpolicy.org/wordpress/2008/09/12/sumit-ganguly-time-to-seize-the-day/>, accessed on October 17, 2008.

23. Andrew Buncombe, "Indian Government Sees off Bribery Charge to Seal Nuclear Deal with the US," Independent (London), July 23, 2008. 
though not hostile, to the American involvement in Pakistan including its seemingly uncritical support for the Pakistani military establishment. The U.S., in turn, has its own reservations about India's role in the region and beyond. Specifically, the Bush administration had misgivings about India's ties to Iran and also about New Delhi's anodyne criticism of the Myanmar military junta's treatment of dissidents. The U.S. and India remain apart in a number of important emergent global regimes ranging from climate change to trade negotiations under the aegis of the World Trade Organization. ${ }^{24}$ Although none of these differences are insurmountable, they will require considerable negotiation and effort to overcome.

The UPA government demonstrated resolve and adroitness in bringing the Indo-U.S. nuclear agreement to fruition; however, officials made little palpable progress in improving relations with India's nettlesome neighbor, Pakistan. This stemmed to some extent from Pakistan's deep-seated and seemingly unending political troubles. ${ }^{25}$ To compound matters, a suicide bomber attacked the Indian embassy in Kabul, Afghanistan, on July 7, killing 54 people including the Indian defense attaché. In early August, the U.S. publicly implicated Pakistan's highly secretive intelligence agency, Inter-Services Intelligence (ISI), in masterminding this attack. ${ }^{26}$ India's foreign secretary, Shiv Shankar Menon, stated that the bombing involved Pakistan and would have adverse consequences for the on-going diplomatic dialogue. ${ }^{27}$ Despite India's evident frustration with Pakistan's likely involvement in the Kabul bombing, efforts were made to keep relations from deteriorating even further. For example, a number of trade and travel agreements were reached between Prime Minister Singh and Pakistani President Asif Ali Zardari while they attended the annual U.N. General Assembly meetings in New York in September.

Any positive developments in Indo-Pakistani relations, however, were called into question in the wake of the devastating terrorist attack on Mumbai (Bombay) on November 26. On this day, a group of ten terrorists struck across the city attacking the Nariman House, a Jewish cultural center, the Oberoi Trident Hotel, the Taj Mahal Hotel, the Leopold Café (a popular outdoor restaurant), the Chattrapati Shijavi railway terminus,

24. Somini Sengupta, "Thirsting for Energy in India's Boomtowns and Beyond," New York Times, March 2, 2008.

25. Sumit Ganguly, "Pakistan's Day of Reckoning," Newsweek, July 21, 2008, available at <http://www.newsweek.com/id/148024>, accessed on October 19, 2008.

26. Mark Mazzetti and Eric Schmitt, "Pakistanis Aided Attack in Kabul, U.S. Officials Say," New York Times, August 1, 2008.

27. "India: Pakistan Behind Kabul Embassy Bomb," MSNBC, available at <http://www. msnbc.msn.com/id/25784603/>, accessed on October 19, 2008. 
and the Bhikaji Cama Children's Hospital. ${ }^{28}$ Over the next 72 hours, they embarked on a killing spree while Indian police and paramilitary forces sought to locate, confront, and overpower them. When the carnage finally ended on November 28, some 173 people (including nine of the attackers) lay dead and scores more were injured. ${ }^{29}$ This terrorist rampage showed that India was woefully ill-equipped to deal with an attack on one of its major metropolitan centers. It also demonstrated that there had been major security and intelligence lapses that permitted an attack of this magnitude to take place against key locations in India's principal entertainment, commercial, and financial capital. ${ }^{30}$

In the aftermath of the attack, Indian police and intelligence authorities, on the basis of telephonic conversations intercepted during the course of the siege, ascertained that the terrorists were members of the long-banned but nevertheless active Pakistan-based terrorist organization, the Lashkare-Taiba (Army of the Righteous). ${ }^{31}$ The Bombay attack was actually only the latest in a series of attacks in various Indian cities traced to terrorist organizations operating from Pakistan. ${ }^{32}$ India responded to the carnage in Bombay by putting its on-going talks with Pakistan on hold and also demanding that Pakistan either hand over or try 40 individuals supposedly living in Pakistan suspected of being involved in acts of terrorism against India. ${ }^{33}$ Pakistan's initial response to these Indian demands was one of denial and defiance, but, in the wake of mounting American and British pressure, it moved against the successor of the Lashkar-e-Taiba, the Jamaat-ud-Dawa (Party of the Righteous Call), by shutting down some of its camps, placing some of its leaders under house arrests, and

28. Prachi Pinglay, "How Mumbai Attacks Unfolded," British Broadcasting Corporation, available at <http://newsvote.bbc.co.uk/mpapps/pagetools/print/news.bbc.co.uk/2hi/south_ asia/7757500.stm?ad=1>, accessed on December 8, 2008. Also see Yaroslav Trofimov, Geeta Anand, Peter Wonacott, and Matthew Rosenberg, "India Security Faulted as Survivors Tell of Terror," Wall Street Journal, December 1, 2008.

29. James Lamont, "India under Fire," Financial Times, December 2, 2008.

30. Sudip Mazumdar, "Flunking the Intelligence Test," Newsweek, November 29, 2008.

31. James Lamont and Farhan Bokhari, "India Calls on Pakistan to Hand over Criminals," Financial Times, December 3, 2008. Also see Jane Perlez and Robert F. Worth, "India Tracing Terror Attack to 2 Militants," New York Times, December 5, 2008; and Praveen Swami, "Mumbai Massacre Story Unfolds in Terrorist's Interrogation," The Hindu, December 2, 2008.

32. Eric Schmitt, Mark Mazzetti, and Jane Perlez, "Pakistan's Spies Aided Group Tied to Mumbai Siege," New York Times, December 8, 2008.

33. These 40 individuals included both Pakistani and Indian citizens. See Jeremy Page, "India Demands Pakistan Hand over 40 Wanted 'Terrorists'," The Times (London), December 11, 2008. 
closing many of its websites. ${ }^{34}$ Despite these initial moves, it is unclear whether Zardari's fledgling democratic regime has the ability or the interest in eviscerating these terrorist organizations, which may be actively supported and encouraged by the ISI. ${ }^{35}$

While no incontrovertible evidence explicitly linking the Bombay terrorist attack to either Zardari's government or the ISI was presented publicly, such connections cannot be realistically ruled out considering the ISI's past ties to a variety of terrorist and jihadi groups operating from within the country's borders. ${ }^{36}$ Whether or not the ISI or any other organ of the Pakistani state actually helped plan or execute the Bombay attack, it is hardly beyond the realm of possibility that Pakistan-based terrorist groups will resort to attacks against India in the future unless Zardari acts aggressively to terminate them. These terrorist organizations, which long enjoyed the patronage of elements within the Pakistani state, may now no longer be within the control of state authorities and may actually be acting unilaterally of them. This remains unclear. In fact, these terrorist groups may actually wish to wreak havoc in India regardless of whether or not they are serving the specific goals or interests of a particular government in Islamabad or the Pakistani state in general. Nonetheless, India has started a major overhaul of its security and intelligence apparatus to deal with such threats in the future. ${ }^{37}$

Sino-Indian relations also remained unsettled, bedeviled by several outstanding issues despite two positive signs: a dramatic surge in trade that is expected to reach $\$ 40$ billion during this fiscal year and Singh's state visit

34. For Pakistan's initial reaction, see Farhan Bokhari and James Lamont, "Pakistan Warns of Threat to Terror War," Financial Times, December 21, 2008. For subsequent reactions, see Dean Nelson, "Pakistan Blinks in India Standoff," The Times, December 14, 2008. Also see Farhan Bokhari and James Lamont, "Pakistan Battles Its Islamist Offspring," Financial Times, December 13/14, 2008.

35. The powerful Pakistani military and ISI played a vital role in spawning, nurturing, and sustaining a range of these organizations initially for use against the Soviets in Afghanistan and then subsequently against India in the disputed territory of Jammu and Kashmir. For a discussion, see Daniel Byman, Deadly Connections: States That Sponsor Terrorism (Cambridge: Cambridge University Press, 2005). For details concerning the ISI's involvement in Afghanistan, see Steve Coll, Ghost Wars: The Secret History of the CIA, Afghanistan, Bin Laden, from the Soviet Invasion to September 10, 2001 (New York: Penguin Books, 2004).

36. John Wilson, "A Preliminary Assessment of the Mumbai Terror Attacks," available at $<$ http://india-alert.blogspot.com/2008/12/preliminary-assessment-of-mumbai-terror.html>, accessed on November 28, 2008.

37. On the lack of Indian preparedness, see Robert F. Worth, "Lack of Preparedness Comes Brutally to Light," New York Times, December 4, 2008; and Sumit Ganguly, "Delhi’s Three Fatal Flaws," Newsweek, December 8, 2008, p. 19. On the overhaul of India's security and intelligence services, see Alan Beattie, "Security Reform Needs Singh to Change Style," Financial Times, December 2, 2008. 
to Beijing in January, where he stressed the need for increased cooperation. ${ }^{38}$ The two states made only glacial progress on the border dispute despite multiple rounds of talks. China continues to equivocate on the status of the former Himalayan state of Sikkim and periodically advances a claim to the Indian state of Arunachal Pradesh. ${ }^{39}$ Furthermore, the presence and activities of over 100,000 Tibetan refugees in India remain a contentious issue in Sino-Indian relations. ${ }^{40}$ During the Beijing Olympics this summer, Indian authorities felt compelled to arrest a large group of young Tibetans when they embarked on a protest march toward the Sino-Indian border. $^{41}$

Quite apart from these regional differences, India and China also remain locked in extra-regional rivalries as they scramble for resources to fuel their growing economies. ${ }^{42}$ For example, India's two-way trade with Africa reached \$25 billion in 2007 compared to \$55 billion for China. Consequently, it is hardly surprising that both countries have been assiduously courting various resource rich states across Africa. Indian policymakers are loath to admit the existence of such a competitive relationship, but it is hardly accidental that India held a summit of 14 African states in New Delhi in April with Thabo Mbeki of South Africa, Meles Zenawi of Ethiopia, and Yoweri Museveni of Uganda in attendance. China had hosted an even larger gathering in $2006 .^{43}$

\section{Conclusion}

The year 2008 in India ended on a mostly somber note in light of the vicious terrorist attack in Bombay. The magnitude of this tragedy largely overshadowed the UPA government's achievements over the course of the year including bringing the revolutionary Indo-U.S. civilian nuclear agreement to fruition, continuing to successfully woo Africa as a source for raw materials and markets, and deftly handling Indo-Pakistani relations immediately after General Pervez Musharraf's tumultuous departure. Yet, after the Bombay terrorist attack, any hope of immediate progress in IndoPakistani relations remains fraught with uncertainty. On the domestic front,

38. Jim Yardley, "Singh Ends China Trip Stressing Joint Benefits; Collaboration Urged, but Disputes Persist," International Herald Tribune, January 16, 2008.

39. India deposed Sikkim's monarch in 1974 and formally absorbed it into India in 1975.

40. Rama Lakshmi, "For India, Tibet Poses Some Delicate Issues," Washington Post, April 2, 2008.

41. Somini Sengupta, "In India, Balancing Refugee Care and Relations with China," New York Times, March 19, 2008.

42. Harry G. Broadman, "India and China Go to Africa: New Deals in the Developing World," Foreign Affairs, March/April 2008, pp. 95-109.

43. "When Trade Winds Smell Sweet: India and Africa," Economist, April 12, 2008. 
the UPA government failed to forge a coherent strategy to confront the rising tide of Naxalite violence, mangled the Amarnath land controversy in Jammu and Kashmir, and proved ineffective in coping with growing ethno-religious violence in various parts of the country. Yet, on a bright note for the UPA government, the results of the state assembly elections in Jammu and Kashmir held in November and December demonstrated that terrorism could not deter ordinary Kashmiris from exercising their right of franchise. In fact, some $60 \%$ of the eligible population turned out to cast their vote in this election. ${ }^{44}$ On the economic front, the UPA government undertook few new initiatives. Instead, it appeared incapable of handling multiple public policy issues simultaneously and remained preoccupied with the demanding exigencies of coalition politics.

The problems facing India in the years ahead transcend the particular shortcomings of the fractious UPA coalition currently in power. Many of these problems are structural and will require the concerted effort of any government coming into power to tackle effectively. These problems involve the underlying weakness of many of India's political institutions, the breakdown of many democratic norms, and the absence of a clear-cut political consensus on a host of critical questions relating to the country's domestic and foreign policy priorities. Unless the next government that comes to power in the national elections scheduled for 2009 can forge a consensus and thereby devise appropriate strategies, India's ability to tackle the problems of endemic poverty, ethno-religious violence, and infrastructural capacity will remain elusive.

44. Rhys Blakely, "Election Setback for Militants with Voter Turnout in Kashmir," The Times, December 30, 2008. 